\title{
Four Ostraca from Thebes
}

\author{
Magdy A.I. Aly \\ Mansoura University
}

\section{Introduction}

The following four ostraca are kept in the Egyptian Museum, Cairo and all have the same inventory number (S.R 18953). They are located in D3East. The four ostraca have one temporary number (T.R 25/1/55/4). The T.R number is indicating the date on which this collection have been brought to the museum, which means they have been brought to the museum in January $25^{\text {th }} 1955$. Four of them belong to the same region "Thebes", either Syene or Elephantine. Only the third ostracon mentions the name of the village Syene. This four ostarca also are part of one big collection in different condition and sizes. Some are good and legible and others are damaged and illegible. 26 documents have been edited in $\mathrm{PhD}$ dissertation by the editor of this paper in April 2009. One of them stands as a good parallel for o. no. 54 . 


\title{
Four Ostraca from Thebes
}

\author{
List of Names \\ O. Cairo S.R.18953, No. 8 \\ $6.4 \times 6.1 \mathrm{~cm}$ \\ Elephantine or Syene? \\ $2^{\text {nd }}$ Cent. CE
}

This relatively small potsherd is a dark brown in color and It has been made of moderate quality pottery. The preserved part is generally in a good condition. The surface has suffered random scratches, minor abrasions and blackened by fire in several spots. It is broken off at the top with an average of 3 to 5 missing lines (according to the shape $\mathrm{f}$ the broken part). Although it seems that the left and bottom edges are softened, the potsherd is broken at these edges. Consequently, some letters are missing at both of them. While the right edge is rather roughed, yet no letters are missing. Only the middle part of the left margin is survived where the upper part is broken off, and it is broken off at bottom. The right margin is preserved. There is a large black blot at the left side, in addition to several small ones here and there. The potsherd has preserved 6 complete lines and 4 incomplete lines.

The text has been written in a dark black ink with a thick nib. The hand is of a medium-sized cursive, with tendency towards ligatures. It's a well-practiced and neat. It shows a consistency in forming the letters. The hand shows clear skills in even interlinear spaces and lines that start almost from the same point. The scribe has used superscripted letters to abbreviate the word (e.g. $\mathrm{T} \imath \theta o \backslash \hat{\eta} /(\varsigma)$ in line $6, \Pi \varepsilon \tau \varepsilon \chi \backslash \hat{\omega} /(v \sigma i \varsigma)$ in line 7 and $\Pi v \backslash \eta^{\prime} /(\pi เ \circ \varsigma), \Pi \alpha \sigma \backslash \eta^{\prime} /(\mu \circ \varsigma)$ in line 8$)$. The hand has the following characteristics: V-shaped kappa with slanting descending stroke to right. Inconsistent size of looped alpha as well as omicron whether large circular or as small as dot. Sigma is lunar and formed by prolonging the horizontal stroke. The $p i$ 


\section{Magdy A.I. Aly}

formed with peak and two legs ending with hook. The omega is broad and remarkable because of the typical curved $\mathrm{W}$-shape even when it is superscripted. The scribe sometimes leaves a space between words and sometimes he just prolongs the last letter of the name before starting write the following name. While the abbreviations are effected with a superscription of the last letter of the name such as the omega of $\Pi \varepsilon \tau \varepsilon \chi \backslash \hat{\omega} /(v \sigma i \varsigma)$ in line 7 and the eta of $\Pi v \backslash \eta ́(\pi 10 \varsigma)$ and $\Pi \alpha \sigma \backslash \eta^{\prime} /(\mu 10 \varsigma)$ in line 8 . There is an obvious diaeresis on the iota of Фañpïs in line 8. Based on palaeographical grounds this document dates back to the second century CE.

This ostracon has been preserved among another group of ostraca, which belong to Thebes (either Elephantine or Syene), which stands a logic indication to the provenance it belongs to. This documents is a list of names, the purpose of this list of names is not certain perhaps for workers involved in liturgical services? And they are not listed in alphabetical order.

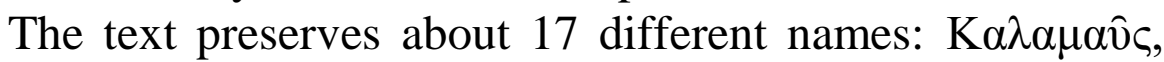

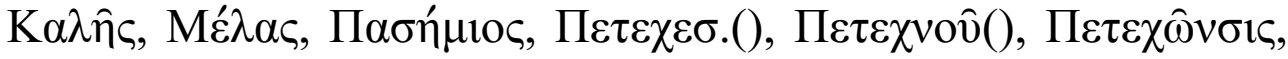

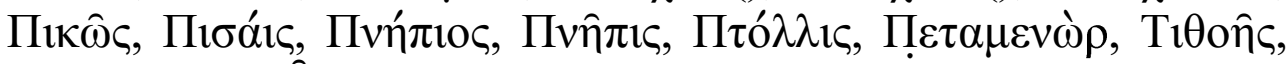

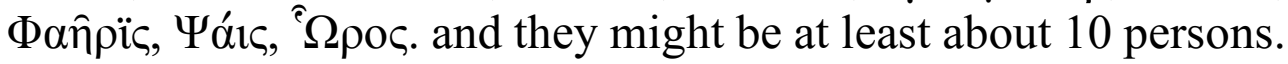
There is exact parallel for this document. The back has no writing. 


\section{Four Ostraca from Thebes}

\section{TRANSCRIPTION}

$1-\ldots.] \chi[$

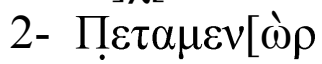

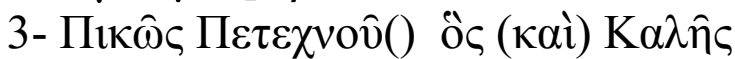

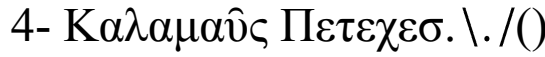

5- Птó $\lambda \lambda 1 \varsigma$ viòs

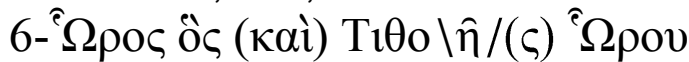

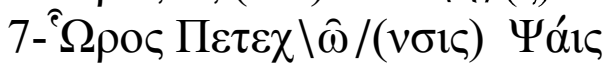

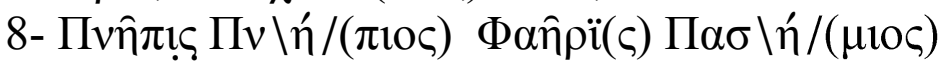

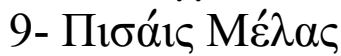

$10-. \lambda .$.

\section{TRANSLATION}

...]ch...

Petamen[or

Pikos son of Petechnou() also called Kales

Kalamaus son of Peteches()

Ptollis the son

Horos also called Tithes son Horos

Horos son of Petechonsis grandson of Psais

Pnepis son Pnepis Phaeris Pasemios

Pisais Melas

1..]

\section{COMMENTARY}

Line $1: \ldots . ..] \chi[$ since the letter chi is legible and an average of the missing letters are about four letters at the beginning, the restoration is confined in limited possibilities. First the missing 


\section{Magdy A.I. Aly}

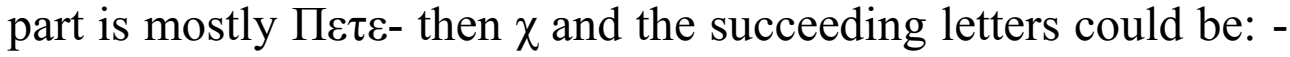

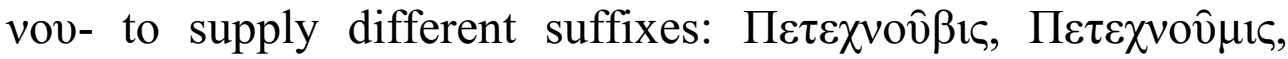

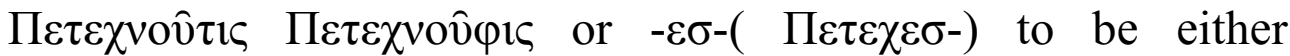

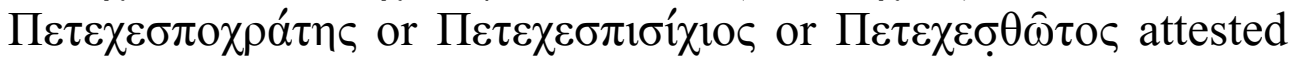

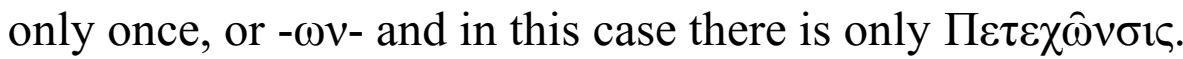

It is worthy to refers to that all the mentioned names in this

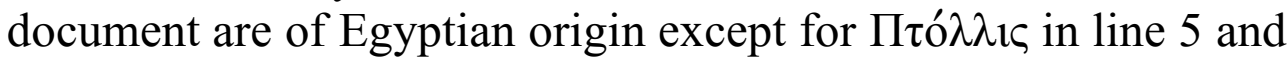
Mć $\lambda \alpha \varsigma$ in line 9. All of them have religious meaning relating to the ancient Egyptian religion; It worthy to mention the meaning of the names in the document; and they are as follows:

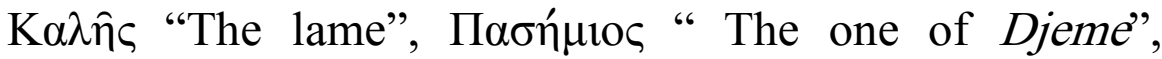

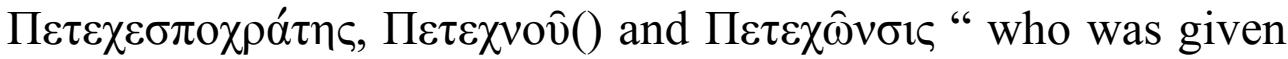

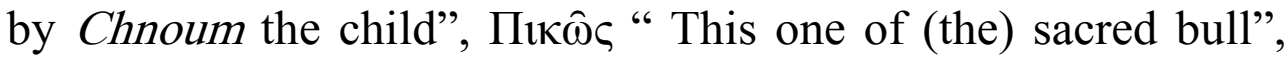

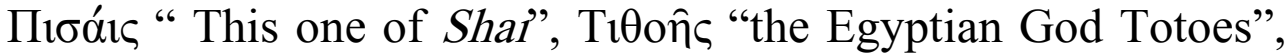

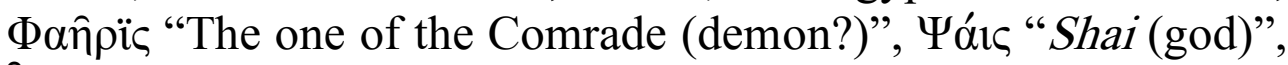
¿תpoc "God Horos".

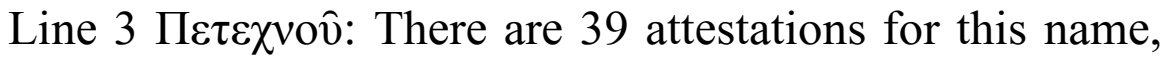
and there are three possible restorations for the suffix of this name: $-\beta 1 \varsigma$ has been attested 14 times, $-\mu 1 \varsigma$ has been attested 22 times, $-\tau \imath \varsigma$ has been attested twice and $-\varphi 1 \varsigma$ has been attested only once. 28 documents from Thebes and the others whether from Alexandria or eastern desert. And by excluding the documents that out of range date we'll get 31 citations.

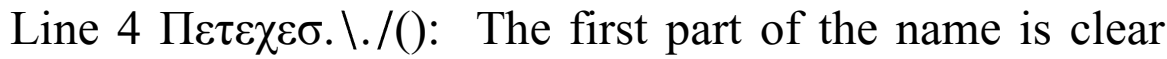
and legible and the restoration is confined in four possibilities as an abbreviated suffix of this name:

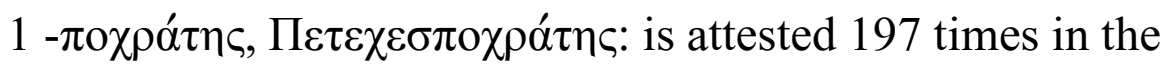
documents. It is also worthy to mention that the form

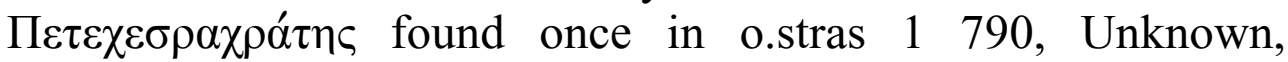




\section{Four Ostraca from Thebes}

Oberägypten, $1 \mathrm{CE}-200 \mathrm{CE}$, as another form of

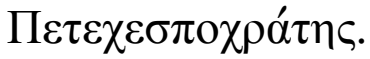

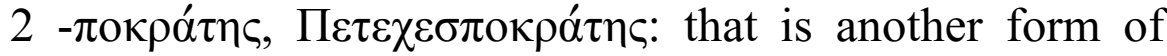

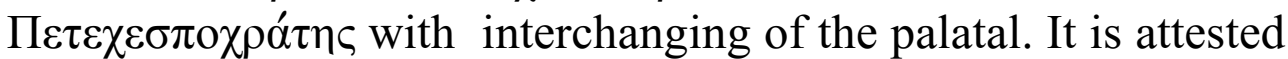
only once in o.stras 2845 , Reçu pour l'impôt des digues et une

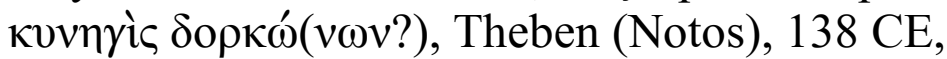

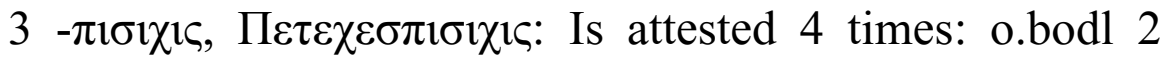
1510, Unknown, Theben, 182 CE, o.bodl 2 1525, Unknown, Theben, 187 CE, o.heid 276, store receipt, Theben (Agorai), 133 CE, o.stras 1 552, Unknown, Theben, $101 \mathrm{CE}$ - $200 \mathrm{CE}$.

$4-\theta \hat{\omega} \tau \circ \varsigma, \Pi \varepsilon \tau \varepsilon \chi \varepsilon \sigma \theta \hat{\omega} \tau o \varsigma:$ is attested only once in o.theb 81, Unknown, Theben, $107 \mathrm{CE}$. The name is found without

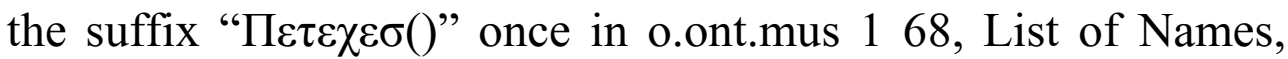
Theben, $101 \mathrm{CE}-300 \mathrm{CE}$.

Line 6 ôs (каi): The relative pronoun is legible, then a horizontal superscripted stroke has been placed over the sigma that mostly refers to the conjunction $\kappa \alpha i$ that is not symbolized in this form elsewhere. In this case the person called also Horos son of Horos alias Tithes son of Horos, which was common.

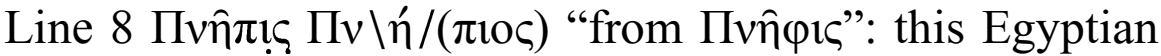
name has been attested only twice in the documents: o.bodl 2 713, unknown, Thebes, $137 \mathrm{CE}$ and o.bodl 2 1664, unknown, Thebes, 115 CE - 155 CE. Only phi changes to be pi and not vice versa, see Gignac, A Grammar of the Greek Papyri (Vol. I Phonology), 1975, p. 89.

Фanpıs: Egyptian, The one of the Comrade (demon?) 270 documents most of them belong to Thebes and the others either 
unknown or uncertain. They are dated between 1 and $200 \mathrm{CE}$ are 222 doc.

One could expect as the end of the document a phrase such

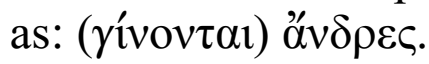

Receipt for Money-Tax on a Palm-Grove

O. Cairo S.R.18953, No. 54

Syene

$12.5 \times 12.2 \mathrm{~cm}$

$138 \mathrm{CE}-161 \mathrm{CE}$

This semi-triangular shaped ostracon, with a base at the top and its vertex at the bottom. It is of light brown color and moderate quality. It is in a good condition and the surface generally is smooth; nevertheless it is marred and partly damaged by scratches, abrasion and brownish decay. The writing is partly faded at line 7 , and it is completely illegible at line 8 . The left edge is regularly cut (mostly in the antiquity), while the top and right edges are broken off. Yet, the upper margin is preserved, as well as the lower margin. The ending of lines 2, 3, 4, 5 and 6 are missing. This ostracon has preserved 8 lines.

The text has been written in dark ink with comparatively thick nib. The scribe occasionally dipped the pen into the inkwell. The hand is neat, fast but careful. The letters characterized by long descenders and they are of medium-sized 


\section{Four Ostraca from Thebes}

cursive with a tendency towards ligatures. The interlinear spaces are narrow, and some letters with long descenders invaded the interlinear space to the following lines. The hand has a general characteristics of the $2^{\text {nd }}$ century $C E$, the iota is long vertical stroke sometimes with a beak, the omicron is mostly as small as a dot. The delta usually extends above the body of the letter sometimes with a hook on top of its left bar. The inconsistent rho formed by a sloping stroke or spine with incomplete head at the top and either with or without a serif. The nu is formed by two parallel stems with a crossbar begins from the top of left stem and extends to cut the right stem just before its top. The scribe abbreviated the words with a superscripted letter. There is no Punctuation or other diacritical marks in the document.

The document dates back to the reign of Emperor Antoninus Pius (see comment on line 5, 6), and during the office

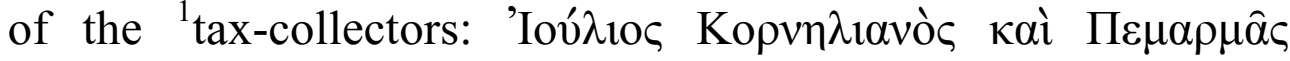

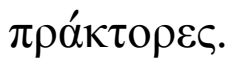

Depending upon the text of the unpublished document this text definitely belongs to Syene in Thebes Region. This document is a Receipt for Money-Tax on a Palm-Grove. The name of the tax-payer is in the missing part of the ostracon, yet the name of person $(\Pi \varepsilon \tau 0 \rho \zeta \mu \eta \hat{\theta} \theta \iota)$ who paid by his name is preserved. O.stras 1 285, Unknown, Elephantine, 148 CE - 149 $\mathrm{CE}$ stands for a good parallel for this document, yet it belongs to Elephantine. There is no writing on the back.

\footnotetext{
${ }^{1}$ These two tax-collectors are mentioned with a specific date(November $12^{\text {th }} 153 \mathrm{CE}$ ) in unpublished document in $\mathrm{PhD}$ dissertation, Magdy A.I Aly, A Group of Unpublished Greek Documentary Papyri and Ostraca from the Egyptian Museum and the University of Michigan. A Study and Investigation. Supervised by Prof. Sayed M. Omar and Prof. Alia H. Hassanein, 2009, Ain Shams University.
} 


\section{Transcription}

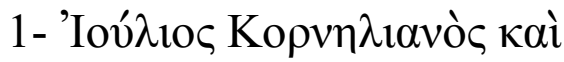

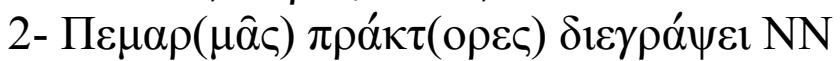

3- بıৎ نं $\pi \dot{\varepsilon} \rho$ óvó $\mu \alpha \tau o \varsigma$

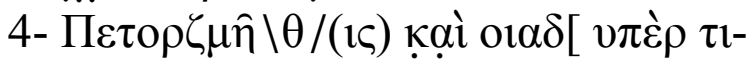

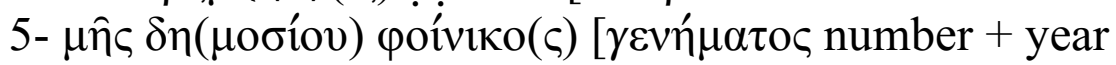

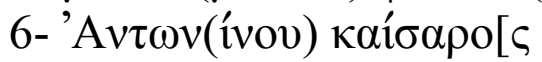

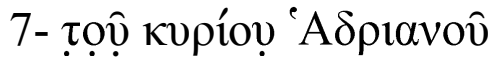

$8-\ldots c$

\section{Translation}

Ioulios son of Cornelianos and Pemarmas the collectors have received in the name of Petorzmethes for the payment of the assessment of dates of the crop for the ... year of Emperor Caesar Antoninus the lord

\section{Commentary}

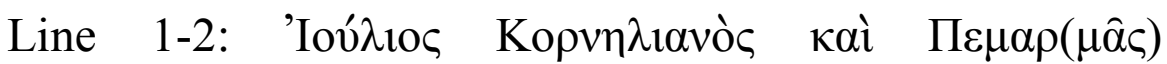
$\pi \rho \alpha \dot{\kappa} \tau(о \rho \varepsilon \varsigma)$ these two tax-collectors are mentioned in the document for the second time. They have been attested only in O. No. 20, dated on 153 CE (See foot note no. 1), which has the following text is:

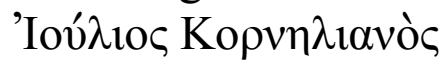

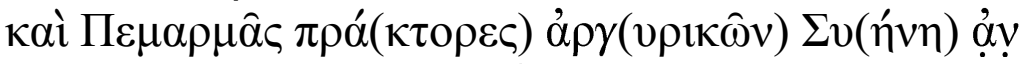

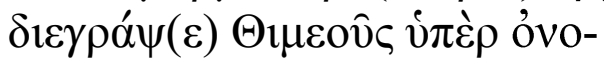

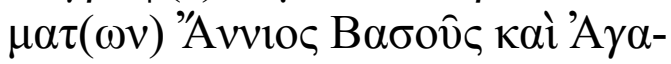

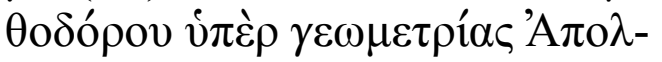

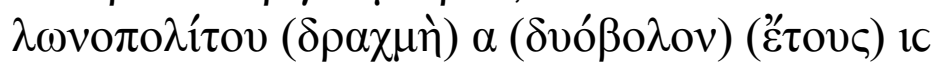

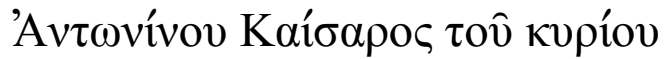

AAvó $\rho$ ıc Pa-mr-iH sA PA- ti-iry-Hms-nfr

Traces of another demotic line 


\section{Four Ostraca from Thebes}

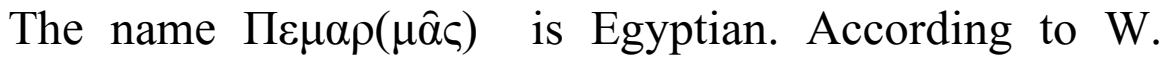
Clarysse (cf. Willy Clarysse, Greek Accents On Egyptian Names, ZPE, 119, 1997, pp. 177-184), and the ending of this name, the accent should be put on ultima.

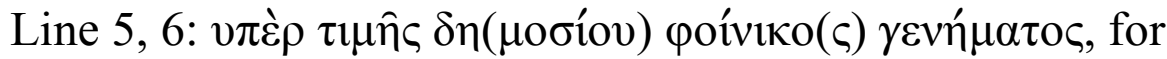
the construction and restoration of this phrase see, o.bodl 2 1003, Unknown, Elephantine, 146 CE, o.bodl 2 1004, Unknown, Elephantine, 149 CE, o.stras 1 285, Unknown, Elephantine, 148 CE - 149 CE, o.wilck 172, Unknown, Elephantine or Syene, 139 CE, o.wilck 227, Unknown, Elephantine, 155 CE, o.wilck 255, Unknown, Elephantine or Syene, 163 CE, o.wilck 257, Unknown, Elephantine, 165 CE, o.wilck 288, Unknown, Elephantine or Syene, 101 CE - 200 CE, o.wilck 1273, Unknown, Elephantine or Syene, $143 \mathrm{CE}$, p.brook 53, Tuн̀ $\Delta \eta \mu$ óíov Фoíviкos, Elephantine, $155 \mathrm{CE}$ - $156 \mathrm{CE}$.

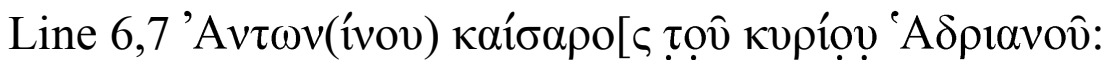

The document dates back to the Emperor Antoninus Pius Who reigned from Wednesday 10 July 138 to Friday 7 March 161 CE. The number of the year lies in the missing part of the potsherd at the end of line 5 . 
Receipt for Trade-Tax

O. Cairo S.R.18953, No. 4

$8.2 \times 5.4 \mathrm{~cm}$

Syene

Thursday June $6^{\text {th }} 142$ CE

This quadrilateral potsherd has a light-tan color. It seems that the ostracon has been broken from a fine quality of pottery. Except for minor scratches and tiny deposits of salt in several parts on the surface, the preserved part of this potsherd is generally in a good condition. In spite of some minor damages at top, left and bottom edges, it seems that they have been regularly cut and softened the draughtsman. The right side is broken off. While is preserved a small margin at the left and top side, a relatively vast margin has been preserved at the bottom. This ostracon has preserved 8 lines, only the last line is complete.

The text has been written in black ink with a thick nib. The hand is of medium-sized cursive with tendency towards ligatures such as the delta and rho in the abbreviated $\delta \rho \alpha \chi(\mu \grave{\varsigma} \varsigma)$ and alpha and iota in кaí⿴囗⿱一一) idiosyncrasies such as the small contracted letters that do not ended with prolonged finials. it seems that the scribe is welltrained and has a business hand. The characteristics of the letters reflects the features of the second century CE. Eta is formed by two stems and crossbar. The delta is generally forms a ligature with the following letter, it has a serif on top of its right bar. The chi is a simple two crossed diagonal strokes without the usual hook in its endings. The iota is a simple vertical stroke without serif or finial. The interlinear spaces are not even, it narrower at the header and tend to be wider at the rest of the document. Some words are linked, except if the previous was abbreviated. The scribe has abbreviated words by superscripted and separated the last letter. Only year and monetary signs are attested. The 


\section{Four Ostraca from Thebes}

document dates back to the $5^{\text {th }}$ year of the reign of Emperor Antoninus Pius (see comment on line 6). It belong to Syene, Thebes, Ombite nome. It is a Receipt for Trade-Tax.

The persons mentioned in this document are: ${ }^{\circ} \mathrm{H} \rho \alpha \kappa \lambda i \delta n \varsigma$ and 'I $I$ 'i $\delta \omega \rho o \varsigma$ (in the missing part of the potsherd) the tax-

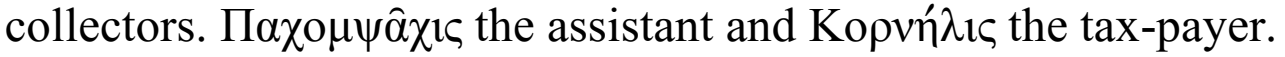

The following documents stand as a good parallel for this document: o.bankes 17, Receipt for $\mu \varepsilon p 1 \sigma \mu o ́ c$, Elephantine, 141

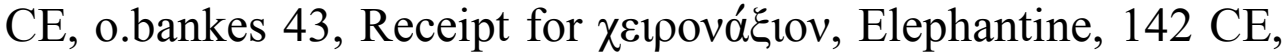
o.bodl 2 1066, Unknown, Elephantine or Syene, 143 CE, o.wilck 181, Unknown, Elephantine or Syene, 141 CE, o.wilck 182, Unknown, Elephantine or Syene, 141 CE, o.wilck 183, Unknown, Elephantine or Syene, 141 CE, o.wilck 188, Unknown, Elephantine or Syene, 142 CE, o.wilck 189, Unknown, Elephantine or Syene, 142 CE, o.wilck 190, Unknown, Elephantine or Syene, 142 CE, o.wilck 191, Unknown, Elephantine or Syene, 142 CE, o.wilck 193, Unknown, Elephantine or Syene, 139 CE - 143 CE, p.eleph.wagner 130 , Receipt of capitation, Elephantine or Syene, 141 CE, p.koeln 2 115, Receipt for Trade Tax, Elephantine or Syene, 142 CE, p.worp 46, Double Receipt for Trade-Tax, Elephantine, 139 CE - 143 CE, sb 69545 20, Steuerquittungen: ..., Elephantine or Syene, 143 CE.

There is no writing on the back. 


\section{TRANSCRIPTION}

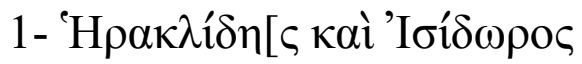

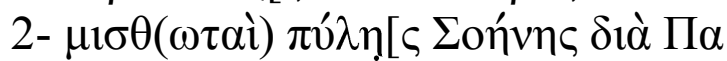

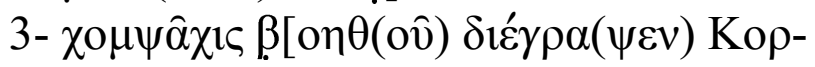

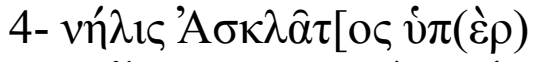

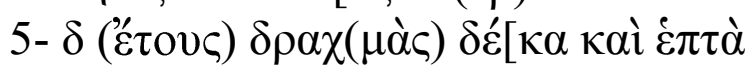

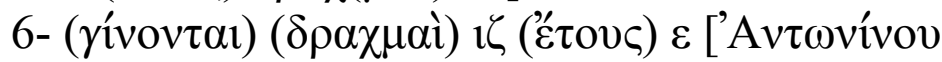

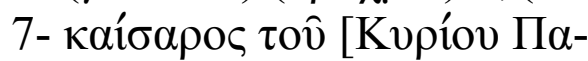

8- vิvi $\overline{\imath \beta}$

\section{CORRECTIONS:}

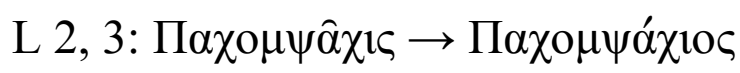

\section{TRANSLATION}

Heracleides [and Isidoros the tax-farmers of the Gate (custom-house) of Syene through the assistant Pachompsachis. Cornelis son of Askl[as], paid for the fourth year seventeen drachmas total 17 drachmas the year $5^{\text {th }}$ of Emperor Caesar Antoninus the lord, Pauni $12^{\text {th }}$.

\section{COMMENTARY}

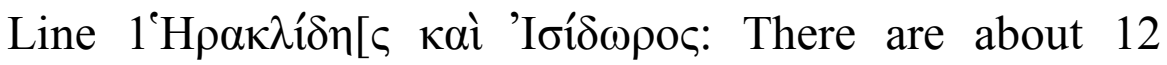
missing letters at the broken part of the end of line 1, which has the name of the second tax-farmer. There are 15 receipts of tax have been cited for these two tax-farmers together, all of them. The $\mu 1 \sigma \theta \omega \tau \alpha i$ begin to appear in the ostraca in the reign of Trajan 


\section{Four Ostraca from Thebes}

and they were issuing receipts for several taxes from 121 to 171 $\mathrm{CE}^{2}$

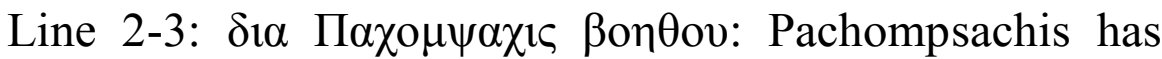
been attested in the documents as assistant to the tax-farmer 299 times the earliest is in 28. Apr. 138 (o.berl 39, Unknown, Elephantine or Syene, $138 \mathrm{CE}$ ), and the latest is in 15 . July 146 (o.wilck 206, Unknown, Elephantine or Syene, $146 \mathrm{CE}$ ).

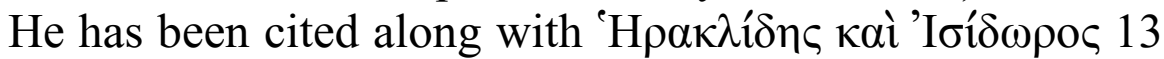
times between 139 and $143 \mathrm{CE}$. He was involving to collect several types of taxes such as: Receipt for $\mu \varepsilon \rho 1 \sigma \mu$ ó, , Receipt for $\chi \varepsilon ı \rho o v a ́ \xi 1 o v$, Receipt for capitation.

Line 4: The construction of the sentence refers to a name of the tax and preceded by the undoubtedly abbreviated preposition $\dot{v} \pi(\grave{\varepsilon} \rho)$; as it has consistently attested. Depending upon the length of line 1, 2 and 3 the average missing letters in the broken right side is ca. 12 letters; where the rest of lines have symbols and can't be taken as a standard length of line.

Consequently, the type of the tax could be deduced where the end of the name of the tax payer and the preposition $i \pi(\grave{\varepsilon} \rho)$ in addition to the name of "abbreviated" tax should be 12 letters, in this case we should have either "assessment" $\mu \varepsilon \rho 1 \sigma(\mu o v)$ or "trade-tax" $\chi \varepsilon i \rho \omega(v \alpha \xi i ́ o v)$, but since the value of payment is 17

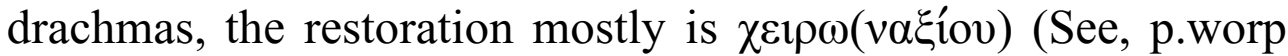
46, Double Receipt for Trade-Tax, Elephantine, 139 CE - 143 $\mathrm{CE})$, rather than $\mu \varepsilon \rho 1 \sigma(\mu \mathrm{ov})$, which has been cited with less value.

${ }^{2}$ See: Wallace, S. Taxation in Egypt from Augustus to Diocletian (Princeton 1938), p299 
Double Birth certificate?
O. Cairo S.R.18953, No. 56
Elephantine or Syene?
$6.4 \times 14 \mathrm{~cm}$
Saturday September $28^{\text {th }} 143 \mathrm{CE}$

This semi quadrilateral potsherd is of dark radish color. It is broken off at the top and right edges and has no margins at these sides. The surface is smooth but marred, without serious affection on the text, by numerous small dots of deposit salt in addition to discoloration that affecting the legibility of the text particularly at lower part. Although the left edge is broken off as well, yet no letters are missing. It seems that the lower side is regularly cut in the antiquity, nevertheless there is no preserved margin at that side. This ostracon has preserved 8 lines; 4 are incomplete and 4 are complete. The ink almost is entirely faded in some words and partly in others. The text has been written on the recto "common softened used side" (i.e. the convex side) with brown ink and a thick nib. It seems that the scribe regularly dipped the pen into the inkwell to provide ink that refers to regularity of his penmanship.

The hand is of medium-sized cursive with almost no ligatures. The hand is slow and careful. Faulty orthography of dittography occurs in line 2, and interchanging between liquid letters in line 6 . The characteristics of this hand represent in: Theta is enlarged and oval with a crossbar sometimes extends to link the following letter. The curved epsilon with its tongue drawn in a separate stroke going out from the middle to connect to the following letter. The upsilon is formed consistently as a Y-Shape. The $n u$ drawn with two parallel stems and a dished crossbar with tiny serif attached to the right stem. The sigma is lunar with a short finial. The alpha in the beginning of the name 


\section{Four Ostraca from Thebes}

of the emperor has been formed as a typical theta in an oval shape.

The interlinear spacing are not even. The scribe remarkably kept a fairly space between words. Only numeral and the year sign are attested in the document. There is no punctuation or other diacritical marks. This document dates back to September $27^{\text {th }} 143 \mathrm{CE}$ during the reign of Emperor Antoninus Pius. This document mostly belong to Thebes, yet it not certain either Syene or Elephantine!

It is a Double Birth certificate? of two girls. Two persons

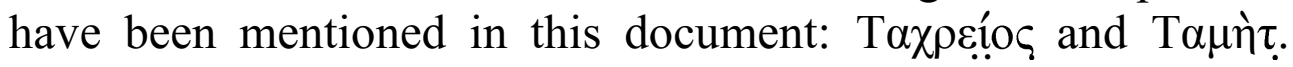
Bothe of them begin with the prefix T $\alpha$ - that refers to a female name. Although it is not the same topic, but p.tebt.tait 50, Horoscope of Sarapammon, Tebtynis (Arsinoites), 145 CE stands for a good parallel of this document. The back has no writing.

\section{Transcription}

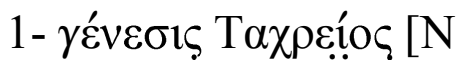

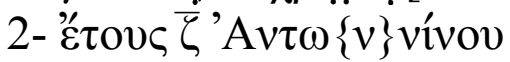

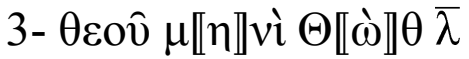

4-

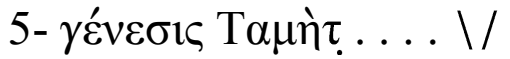

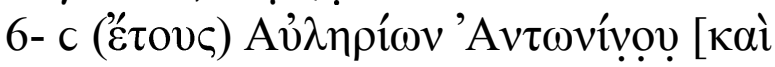

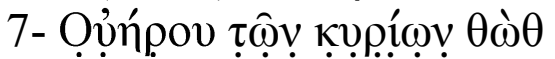

8- $\quad \bar{\lambda}$

9- $\omega \rho \ldots$ 


\section{Translation}

The "official" birth of Tachres of the $7^{\text {th }}$ year of Antoninus the God, in the $30^{\text {th }}$ of the month Thoth, in the second hour of the night, the "official" birth of Ta-mtr of the $6^{\text {th }}$ year of Aurelius Antoninus and (Aurelius) Verus the lords, in the $30^{\text {th }}$ of the month Thoth, ...

\section{Commentary}

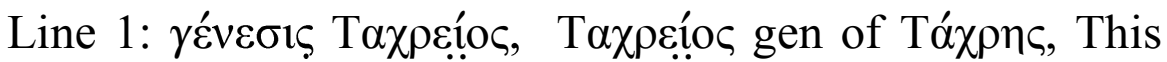
Egyptian name has been attested once in p.lond 2 257, unknown, Ptolemais Euergetis (Arsinoites), 94 CE - 95 CE. A patronymic name mostly is in the missing part.

Line $2-3$ : 'Av $\tau \omega\{v\}$ vívov $\theta \varepsilon \circ \hat{v}$, It is not common to see the name of the emperor as a deity in this sequence, but rather vice versa.

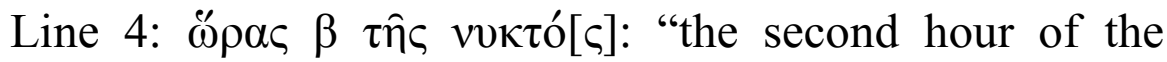
night" The day starts from sunrise at about 6 a.m. till sunset at about 6 p.m., is divided into 12 hours (Cf. P. Lond. 7 1973). The night is divided in the same way (i.e. starts from sunset at about 6 p.m. till sunrise at about 6 a.m.). Consequently, the baby girl has been born according to the document about at about 8 p.m. of local time on Saturday September $28^{\text {th }} 143$ CE.

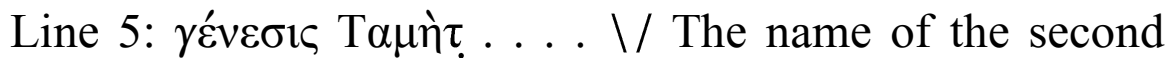
child, which is also a girl is an Egyptian and is undeclined. It means "the one of the sacred emblem (of Chnoum)". The patronymic name is illegible and abbreviated and doubted letters 


\section{Four Ostraca from Thebes}

could be figured out: $\sigma \alpha v \tau \alpha()$. It seems that the baby girl Ta-mtr in the same time and date of Tachres (See note on line 9).

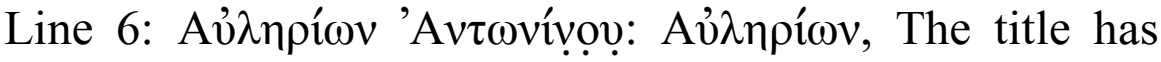
been cited with interchanging between the two liquid vowels 43 times in the document. For this common error of the liquids interchanging (lambda and rho) see Gignac, A Grammar of the Greek Papyri (Vol. I Phonology), 1975, p. 104. Marcus Aurelius and Lucius Verus, ruled together from Saturday 8 March 161 to Sunday 23 January 169, and the $6^{\text {th }}$ year of the reign of the two emperors is Saturday September $28^{\text {th }} 143$ CE.

Line 9: There are traces of doubtful omega and illegible rho, is there is a possibility to be $\omega \rho \alpha \varsigma$, that would refers to another time in which the second baby was born and they were not born in the same time. 
Magdy A.I. Aly

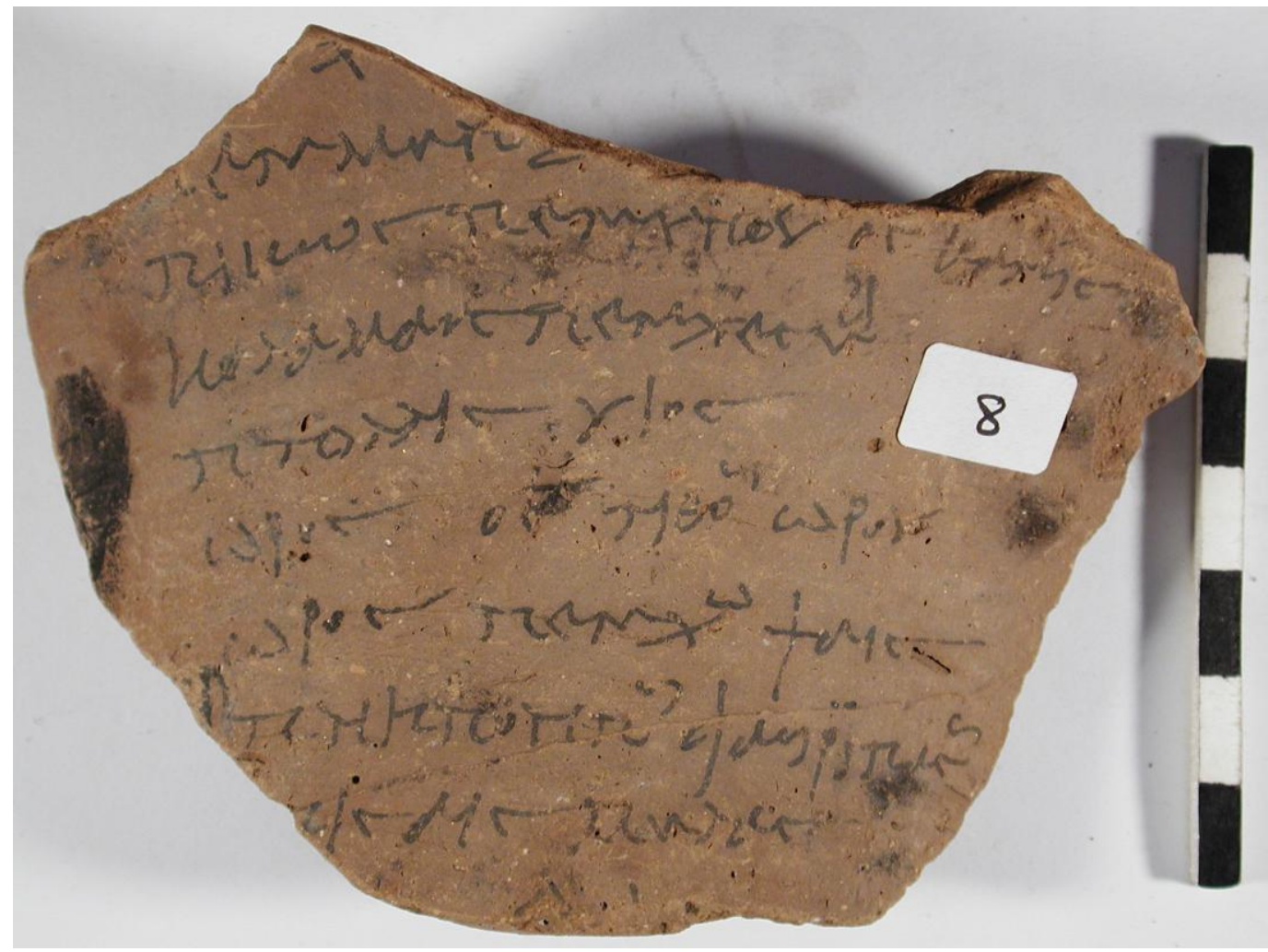

O. No 8

List of Names 
Four Ostraca from Thebes

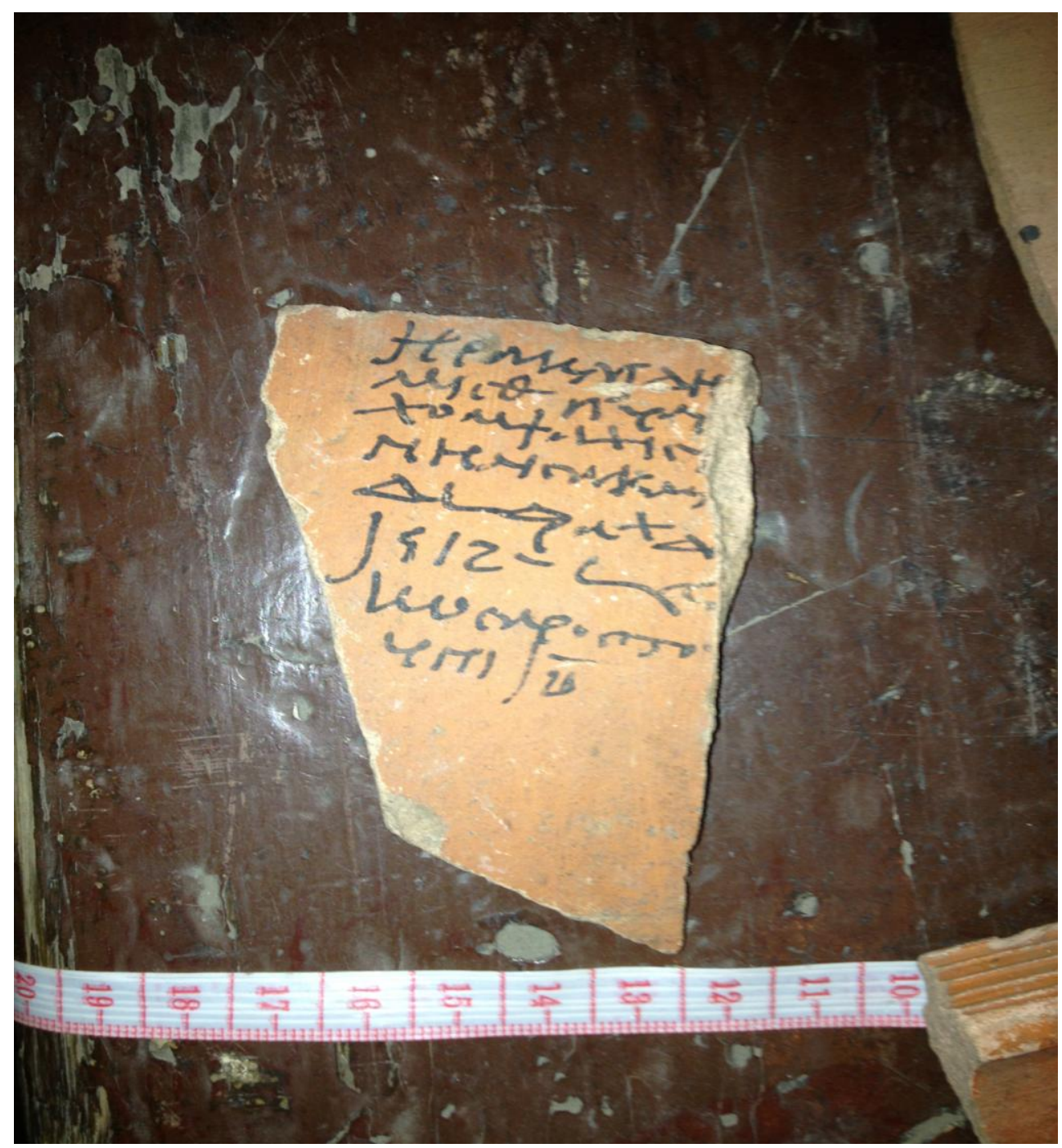

O. No 4

Receipt for Trade-Tax 
Magdy A.I. Aly

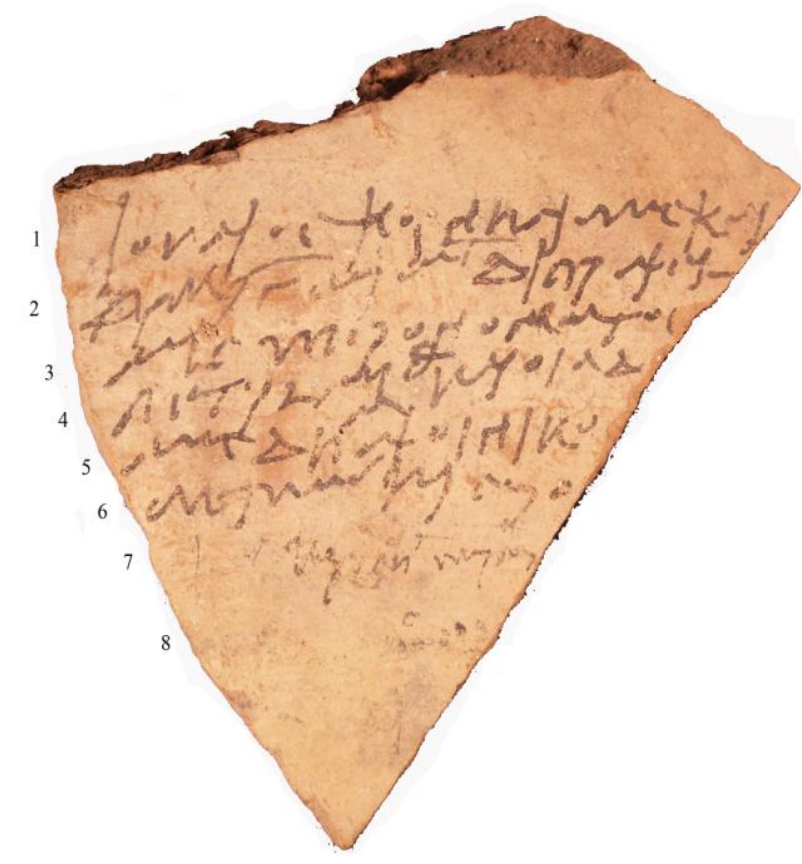

O. No. 54

Receipt for Money-Tax on a Palm-Grove 
Four Ostraca from Thebes

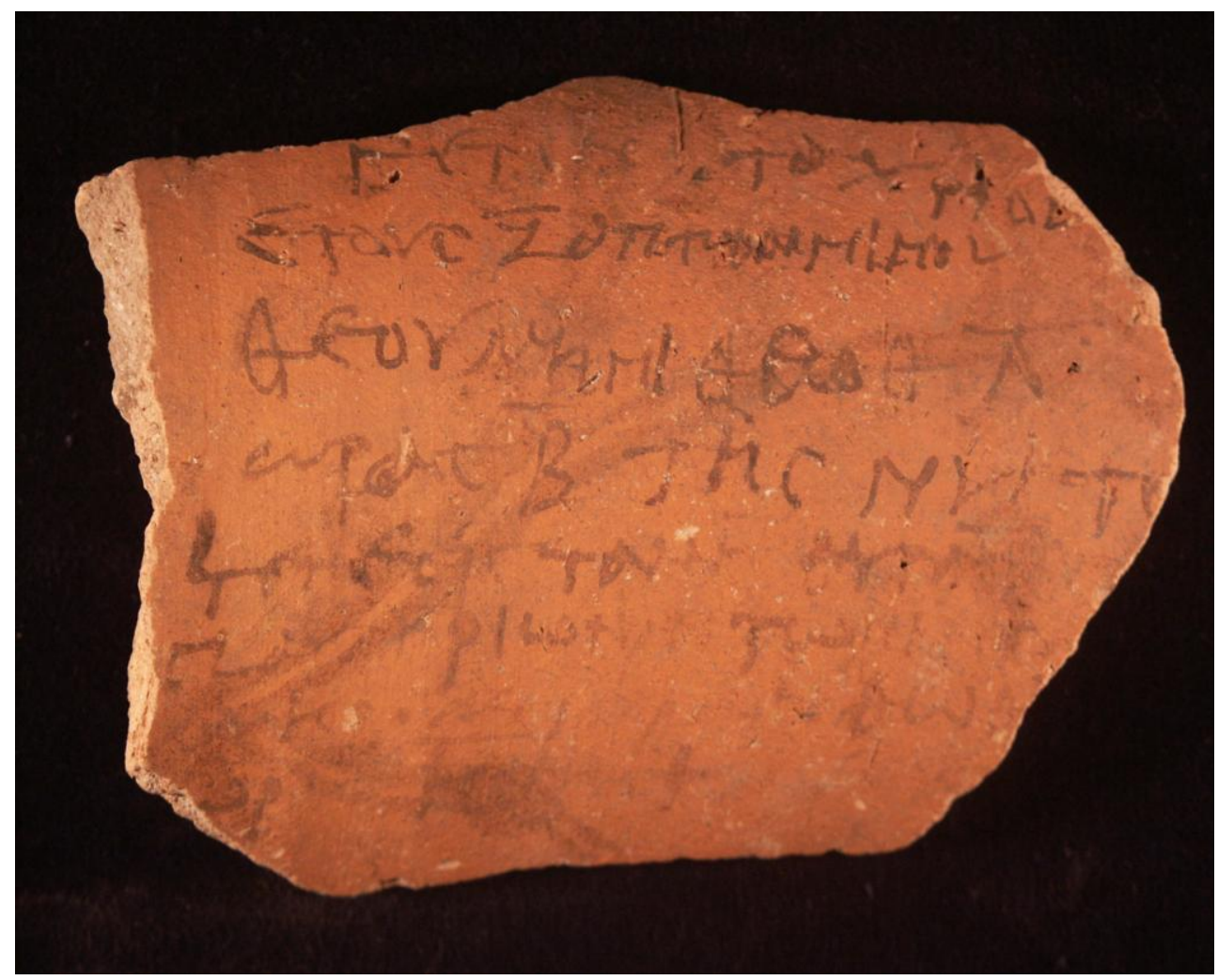

O. No 56

Double Birth certificate? 